\title{
PENGARUH KETIDAKPASTIAN LINGKUNGAN DAN STRATEGI KOMPETITIF TERHADAP HUBUNGAN SISTEM KONTROL AKUNTANSI DENGAN KINERJA PERUSAHAAN PERBANKAN DI KOTA MEDAN
}

\author{
James Ronal Tambunan \\ Correspondent Email: jamesronaldtambunan@gmail.com
}

Received: 2021-02-10, Revised: 2021-03-20, Accepted: 2021-03-25

\begin{abstract}
Abstrak
Penelitian ini bertujuan untuk mengetahui pengaruh ketidakpastian lingkungan dan strategi kompetitif terhadap hubungan sistem kontrol akuntansi dengan kinerja perusahaan perbankan di kota medan. Metode yang digunakan dalam pemilihan sampel adalah metode purposive sampling. Hasil penelitian menunjukkan adanya pengaruh secara parsial dan simultan hasil efektivitas ketidakpastian lingkungan yang diukur melalui persepsi top manajer terhadap hubungan sistem kontrol akuntansi dan kinerja perusahaan namun dapat memberikan isyarat bahwa ketidakpastian lingkungan yang dipersepsikan top manajer sesuai dengangan kondisi aktual.
\end{abstract}

Kata-kata kunci: lingkungan belajar, kinerja, kontrol akuntansi.

\section{PENDAHULUAN}

\section{Latar Belakang Penelitian}

Beberapa penelitian yang telah membuktikan bahwa efektivitas penggunaan sistem kontrol akutansi dalam rangka peningkatan kinerja perusahaan dipengaruhi oleh beberapa faktor kontinjensi diantaranya besar perusahaan, diversifikasi bisnis, dan tingkat disentralisasi (Merchant, 1981), teknologi produksi dan faktor - faktor pasar

Penelitian ini menggunakan ketidakpastian lingkungan yang dipersepsikan (perceived environmental uncertainty) dan strategi kompetitif sebagai variabel kontinjensi. Terdapat alasan penggunaan dua variabel kontinjensi ini yaitu:

Pertama, ketidakpastian lingkungan yang dipersepsikan top manajer merupakan faktor kontinjensi yang paling penting mempengaruhi pengambilan keputusan manajerial perusahaan. Ketidakpastian lingkungan yang dipersepsikan (top manajer) menjadikan proses perencanaan dan kontrol lebih sulit atau kompleks (Chenhall dan Morris, 1986). Kedua, strategi kompetitif memiliki hubungan yang erat dengan sistem kontrol termasuk sistem kontrol akuntansi. Menurut Anthony dan Govindarajan (1998) mengatakan bahwa sistem kontrol merupakan alat untuk mengimplementasikan strategi sedangkan strategi adalah rencana untuk pencapaian tujuan organisasi. 
Chenhall dan Morris(1986), Gul dan Chia (1994), dan Kren dan Kerr (1993) mengatakan bahwa penelitian ini dilakukan karena belum konkritnya bukti empiris mengenai pengaruh ketidakpastian lingkungan terhadap hubungan sistem kontrol akuntansi dengan kinerja perusahaan sehingga hasilnya belum konklusif membuktikan argumen teoritis yang dinyatakan Penelitian - penelitian yang dilakukan Simons (1987), Mak (1989), serta Sim dan Teoh (1999) mengukur ketidakpastian lingkungan dengan menggunakan persepsi top manajer sedangkan Muchammad Syafruddin (2000) mengukurnya dengan mengobservasi kondisi ketidakpastian lingkungan aktual yang dihadapi perusahaan.

Hasil-hasil penelitian tersebut secara empiris dapat menjelaskan bahwa ketidakpastian lingkungan yang diukur berbeda sama-sama berpengaruh positif terhadap hubungan sistem kontrol akuntansi dengan kinerja perusahaan. Secara teoritis Gul dan Chia (1994) serta Kerr dan Kren (1993) menegaskan bahwa ketidakpastian lingkungan yang dipersepsikan top manajer lebih baik daripada ketidakpastian lingkungan aktual, karena ketidakpastian lingkungan yang dipersepsikan top manajer tersebut berpengaruh terhadap keputusan-keputusan yang dibuat manajemen dalam merespon lingkungan operasional perusahaan

Penelitian ini menggunakan ketidakpastian lingkungan yang dipersepsikan top manajer untuk mengukur ketidakpastian lingkungan yang mempengaruhi perusahaan, berbeda dengan penelitian Muchammad Syafruddin (2000) yang menggunakan ketidakpastian lingkungan aktual. Penelitian ini penting dilakukan sebagai salah satu usaha mengeneralisasi hasil-hasil penelitian-penelitian yang menggunakan persepsi top manajer untuk mengukur ketidakpastian lingkungan yang dihadapi perusahaan sekaligus membuktikan pengaruhnya terhadap hubungan sitem kontrol akuntansi dengan kinerja perusahaan. Motivasi yang lain yaitu adanya kontradiksi hasil riset tentang pengaruh strategi kompetitif yang digunakan perusahaan terhadap hubungan sistem kontrol akuntansi dengan kinerja perusahaan.

Penelitian Govindarajan dan Gupta (1985), Govindarajan (1988) dan Govindarajan dan Fisher (1990) yang mendukung proposisi Miles dan Snow (1978) bahwa perusahaan prospector (dalam konsep Porter disebut differentiation) cenderung kurang menekankan penggunaan sistem kontrol akuntansi dan sebaliknya prusahaan defender (cost leadership) menekankan penggunaan sistem kontrol akuntansi. Hasil-hasil penelitian tersebut bertentangan dengan hasil penelitian dilakukan Simons (1987) yang menyatakan bahwa perusahaan - perusahaan yang menggunakan strategi build atau prospector (differentiation) lebih menekankan penggunaan sistem kontrol akuntansi dibandingkan perusahaan-perusahaan yang menggunakan strategi harvest atau defender(cost leadership).

Kontradiksi temuan riset ini mengakibatkan ketidakjelasan dukungan bukti empiris terhadap teori yang diproposisikan oleh Miles dan Snow (1978). Menemukan bukti empiris baru tentang pengaruh strategi kompetitif yang digunakan perusahaan terhadap hubungan sistem kontrol akuntansi dengan kinerja perusahaan merupakan alasan pentingnya penelitian ini dilakukan. Kaplan (1984) merekomendasikan pentingnya riset-riset dilakukan terus menerus untuk memenuhi perkembangan (perubahan) lingkungan kompetisi dan tuntutan praktik sistem kontrol dan akuntansi kos.

Penelitian ini menggunakan konsep strategi kompetitif yang ditawarkan oleh Porter (1980), berbeda dengan yang digunakan dalam penelitian Simons (1987) yang menggunakan konsep Miles dan Snow (1978). Konsep Porter (1980) digunakan dalam penelitian ini karena secara statistik konsep ini memiliki alat uji validitas konstruk yang didemonstrasikan oleh Govindarajan dan Fisher (1990). Ketersediaan alat uji validitas konstruk ini dapat mendeteksi secara statistik ketepatan responden mengidentifikasi strategi kompetitif yang diterapkan perusahaan. Simons (1987) menguji validitas konstruk strategi kompetitif dengan menggunakan metode wawancara langsung pada tiga puluh responden yang telah mengidentifikasi strategi kompetitif yang diterapkan perusahaan reponden. 
Miliken (1987) menyatakan bahwa salah satu bagian dari ketidakpastian lingkungan adalah strategi yang digunakan perusahaan untuk berkompetisi. Pernyataan ini menegaskan bahwa strategi kompetitif merupakan bagian dari dimensi variabel ketidakpastian lingkungan yang kalau diuji dengan pendekatan interaksi regresi berganda sebagaimana yang telah biasa digunakan dalam penelitianpenelitian akuntansi manajemen, maka akan mengakibatkan terjadinya multicollinearity antara variabel independen termasuk variabel interaksi.Hal ini kemungkinan besar menghasilkan kesimpulan yang bias.

Untuk mengatasi permasalahan tersebut maka penelitian ini menggunakan teknik analisis residual (residual analysis) yang digunakan dalam penelitian Dewar dan Werbel (1979), Drazin dan Van de ven (1985), Duncan dan Moores (1989), dan Bambang Riyanto L.S (1999; 2001). Analisis residual mengutamakan ukuran tingkat ketidaksesuaian (lack of fit) antara variabel kontinjensi dan variabel sistem. Tingkat ketidaksesuaian dikorelasikan dengan kinerja perusahaan disyaratkan signifikan negatif sehingga secara umum dapat mendukung proposisi teori kontinjensi bahwa kesesuaian yang tinggi (ketidaksesuaian yang rendah) antara variabel sistem dengan variabel kontinjensi akan meningkatkan kinerja perusahaan. Duncan dan Moores (1989) menyatakan bahwa analisis residual akan berpotensi mengembangkan suatu model yang fit dalam studi-studi teori kontinjensi di masa yang akan datang. Penelitian ini juga merupakan suatu usaha untuk membuktikan efektivitas penggunaan analisis residual dalam penelitian yang berbasis pada teori kontinjensi.

\section{Perumusan Masalah}

Secara umum penelitian ini ingin menjawab permasalahan tentang realisasi proposisi teori kontinjensi tersebut namun digunakan logika kebalikan dengan menguji seberapa besar pengaruh lack of fit (ketidaksesuaian) atau disebut juga residual. Jika nilai residual (ketidaksesuaian) berhubungan negatif dengan kinerja perusahaan maka kesesuaian ( fit) antara variabel sistem kontrol dan variabel kontinjensi akan berhubugan positif dengan kinerja. Hal ini dapat diartikan bahwa variabel kontinjensi berpengaruh positif terhadap hubungan sistem kontrol dengan kinerja perusahaan.

Menggunakan logika pengujian seperti ini akan membebaskan model penelitian dari masalah multicollinearity yang terjadi jika menggunakan logika pengujian pendekatan interaksi. Oleh karena itu secara spesifik rumusan masalah penelitian ini adalah sebagai berikut :

1. Apakah terdapat pengaruh ketidakpastian lingkungan yang dipersepsikan terhadap hubungan sistem kontrol akuntansi dengan kinerja perusahaan dibuktikan dengan adanya hubungan negatif antara kinerja perusahaan dengan nilai residual sistem kontrol akuntansi dan ketidakpastian lingkungan yang dipersepsikan top manajer.

2. Apakah terdapat pengaruh strategi kompetitif terhadap hubungan sistem kontrol akuntansi dengan kinerja perusahaan dibuktikan dengan adanya hubungan negatif antara kinerja perusahaan dengan nilai residual sistem kontrol akuntansi dan strategi kompetitif yang digunakan perusahaan.

Perbedaan penelitian ini dengan penelitian - penelitian sebelumnya adalah pada penggunaan sampel penelitian perusahaan jasa perbankan. Penelitian -penelitian sebelumnya dengan topik yang sama meneliti pada sampel perusahaan manufaktur. Menemukan bukti empiris pada perusahaan perbankan menjadi penting melihat begitu pesatnya persaingan usaha di sektor tersebut dan keunikan strategi yang dapt diambil perusahaan perbankan bukan berlandaskan tekstur, content, dan fitur produk dalam bentuk fisik sebagaimana yang dihasilkan industri manufaktur. 


\section{Tujuan Dan Manfaat Penelitian}

Tujuan penelitian ini dilakukan adalah untuk membuktikan terdapat pengaruh teori kontinjensi dalam operasionalisasi perusahaan khususnya pada industri perbankan. Sehingga penelitian ini dapat memberikan manfaat pada pengembangan teori akuntans dan berkaitan dengan akuntansi manajemen. Manfaat dari penelitian ini secara praktis bagi perusahaan yaitu: dapat mendesain sistem kontrol dengan mempertimbangkan faktro ketidakpastian lingkungan yang dipersepsikan oleh top manajer dan strategi kompetitf yang diterapkan perusahaan sehingga tercipta efektifitas organisasi.

\section{KERANGKA TEORI}

\section{Ketidakpastian Lingkungan yang Dipersepsikan, Sistem Kontrol Akuntansi,}

\section{dan Kinerja Perusahaan}

Penelitian Simons (1987) menemukan bahwa dibandingkan perusahaan defender, perusahaan prospector yang menggunakan sistem kontrol akuntansi lebih intensif mampu menghasilkan kinerja yang tinggi dalam lingkungan yang dinamis. Hasil penelitian menolak proposisi yang dinyatakan Miles dan Snow (1978) dalam Smith (1997) bahwa semua perusahaan yang menerapkan strategi berbeda dapat sama-sama menghasilkan kinerja terbaik dalam lingkungan yang sama.

Penelitian Simons (1987) menemukan 10 dimensi sistem kontrol akuntansi yaitu :

1. Sasaran anggaran yang ketat ( tight budget goals), yaitu tingkat keketatan anggaran dalam mencapai sasaran anggaran (pertanyaan no. 8, 23, 24, 25, 32)

2. Pengamatan eksternal (external scanning), yaitu tingkat penggunaan sistem kontrol akutansi dalam membaca dan menyimpulkan situasi dan lingkungan eksternal (pertanyaan no. $1,11,15)$.

3. Monitoring output (result monitoring), yaitu tingkat penggunaan sistem kontrol akuntansi dalam memonitor hasil kerja para manajer (pernyataan no. 12, 21,23).

4. Kontrol kos (cost control), yaitu tingkat penggunaan teknik analisis dan kontrol kos sebagai bagian sistem atau alat kontrol akuntansi (pertanyaan no. 2, 4,18).

5. Data ramalan (forcast data), yaitu tingkat penggunaan data ramalan dalam laporan kontrol (pernyataan no. 6).

6. Sasaran dihubungkan dengan output (goal related to output), yaitu tingkat penggunaan sistem yang menghubungkan sasaran anggaran dengan efektivitas hasil (pertanyaan no. 16, 17).

Pelaporan berkala (reporting frequency), yaitu tingkat penggunaan laporan berkala (pertanyaan no.27).

7. Pemberian bonus berdasarkan formula (formula - based bonus remuneration), yaitu tingkat penggunaan sistem pemberian bonus berbasis pencapai target budget (pertanyaan no.20,28). 
8. Penyesuaian sistem kontrol (tailored control system), yaitu tingkat penyesuaian sistem kontrol akuntansi yang digunakan organisasi dengan lingkungan perusahaan diasosiasikan dengan laporan kontrol yang rinci (pertanyaan no. 26, 29).

9. Kemampuan perubahan sistem kontrol (control system changeability), yaitu tingkat kemampuan perubahan sistem kontrol akuntansi dan kepentingan untuk melakukan komunikasi informal dalam rangka menyebarkan informasi kontrol

(pertanyaan no. 22,31).

Mak (1989) meneliti pengaruh tingkat kesesuaian antara sistem kontrol manajemen dengan ketidakpastian lingkungan yang dipersepsikan terhadap kinerja keuangan perusahaan. Penelitian ini menggunakan responden top manajer dari sampel 74 perusahaan manufaktur yang go public di Selandia Baru dan menemukan bahwa kesesuaian antara sistem kontrol operasional (meliputi standar kos, analisis varian untuk kontrol kos, dan teknik riset operasional untuk kontrol inventori) dengan ketidakpastian lingkungan yang dipersepsikan top manajer berpengaruh positif terhadap kinerja keuangan perusahaan.

Penelitian Sim dan Teoh (1999) dengan menggunakan instrumen sistem kontrol akutansi yang dikembangkan oleh Simons (1987), menemukan bahwa penggunaan sistem kontrol akutansi (hanya perubahan sistem kontrol) dipengaruhi oleh ketidakpastian lingkungan yang dirasakan oleh CEO dari 165 perusahaan manufaktur di Malaysia dan Singapura. Penelitian di Indonesia dilakukan oleh Muchammad Syafruddin (2000) dengan menggunakan sampel industri jasa keuangan khususnya Bank Perkreditan Rakyat (BPR) yang beroperasi di Jawa Tengah dan hanya menggunakan 3 dimensi sistem kontrol akuntansi (keketatan tujuan anggaran, sistem kontrol kos, dan penyesuaian sistem kontrol akuntansi) dari 10 dimensi sistem kontrol akuntansi yang diajukan Simons (1987). Penelitian ini menemukan bahwa dinamika lingkungan mampu memoderasi hubungan sistem kontrol akuntansi ( hanya keketatan tujuan anggaran dan sistem kontrol kos) dengan kinerja perusahaan. Semakin tinggi tingkat dinamika lingkungan maka semakin tinggi pula hubungan sistem kontrol akuntansi dan kinertja organisasi. Dinamika lingkungan tidak diukur melalui persepsi top manajer namun melalui pengamatan lingkungan perusahaan secara langsung oleh peneliti.

Hasil-hasil penelitian tersebut belum memberi bukti yang konkrit dan membingungkan karena adanya perbedaan pengukuran ketidakpastian lingkungan, menggunakan persepsi top manajer atau pengamatan langsung namun menghasilkan pengaruh posistif yang sama terhadap hubungan sistem kontrol akuntansi dengan kinerja perusahaan. Gul dan Chia (1994) serta Kren dan Kerr (1993) menegaskan bahwa ketidakpastian lingkungan yang dipersepsikan top manajemen lebih baik dari pada ketidakpastian lingkungan aktual, karena lebih mempengaruhi pengambilan keputusan manajerial perusahaan terutama keputusan kontrol perusahaan yang akhirnya mempengaruhi kinerja perusahaan

\section{Strategi Kompetitif, Sistem Kontrol Akuntansi, dan Kinerja Perusahaan}

Beberapa penelitian terdahulu telah membuktikan adanya hubungan antara penerapan strategi kompetitif dengan sistem kontrol akuntansi. Kandwalla $(1972 ; 1973)$ dalam Simons $(1990)$ menemukan bahwa adanya peningkatan kompetisi dipengaruhi oleh peningkatan penggunaan sistem kontrol akuntansi. Hubungan ini kuat dalam kompetisi produk moderat dalam kompetisi marketing dan rendah dalam kompetisi harga. Penelitian ini menguji hubungan antara sistem kontrol formal (akuntansi) dan ligkungan eksternal perusahaan, temuan penelitian tersebut mengungkapkan bahwa desain sistem kontrol akuntansi sensitif terhadap cara perusahaan berkompetisi. Penelitian Kandwalla (1972) merupakan bukti empiris petama tentang hubungan antara sistem kontrol akuntansi dengan tingkat 
kompetisi dan memberikan kontribusi pengetahuan mengenai hubungan sistem kontrol akuntansi dan strategi.

Sim dan Teoh (1999) menjelaskan bahwa penelitian Miller dan Friesen (1982) menemukan sistem kontrol akuntansi efektif digunakan pada perusahaan conservative (atau dalam konsep Porter disebut cost leadership) dan tidak efektif digunakan pada perusahaan enterpreneurial (diffrentiation). Hasil penelitian yang dilakukan oleh Govindarajan (1988) dalam Smith (1997) menemukan bahwa perusahaan dengan strategi low cost (cost leadership) berkinerja tinggi jika penghargaan (bonus) diberikan berdasarkan pencapaian target anggaran ( salah satu dimensi sistem kontrol akuntansi ). Penelitian yang dilakukan Govindarajan dan Fisher (1990) menemukan bahwa perusahaan yang menggunakan sistem kontrol out put (bagian sistem kontrol akuntansi) dan strategi cost leadership mampu meningkatkan kinerja organisasi.

Govindarajan dan Gupta (1985) dalam Smith (1997) menemukan hubungan positif antara pemberian bonus (salah satu aspek sistem kontrol akuntansi) dengan efektivitas penerapan strategi "harvest" (cost leadership) menghasilkan kinerja yang meningkat dan menyimpulkan bahwa strategi kompetitif sebagai variabel moderating (kontinjensi) terhadap efektivitas sistem kontrol akuntansi dalam rangka peningkatan kinerja perusahaan. Kinerja perusahaan dalam penelitian ini diukur 
menggunakan instrumen pengukuran kinerja perusahaan secara overall baik finansial maupun nonfinansial.

Temuan-temuan penelitian tersebut mendukung proposisi yang diajukan oleh Miles dan Snow (1978) bahwa prusahaan prospector (dalam konsep Porter disebut diffrentiation) cenderung kurang menggunakan sistem kontrol akuntansi (untuk menghasilkan kinerja) untuk melakukan inovasi sebaliknya prusahaan defender (cost leadership) mengunakan sistem kontrol akuntansi (untuk menghasilkan kinerja).

Penelitian empiris berikutnya yang meyelidiki pengaruh strategi kompetitif terhadap hubungan sistem kontrol akuntansi dengan kinerja perusahaan dilakukan Simons (1987) pada 76 perusahaan manufaktur. Dengan menggunakan konsep Miles dan Snow penelitian ini menemukan perusahaan prospector menghasilkan kinerja tinggi dengan menggunakan sistem kontrol akuntansi meliputi keketatan tujuan anggaran, peramalan data dan memonitor output tetapi tidak pada kontrol kos . Selain itu perusahaan prospector menggunakan pelaporan berkala dan sistem kontrol yang dapat disesuaikan.

Pada kenyataannya terjadi kontradiksi hasil penelitian antara penelitian Govindarajan (1988); Govindarajan dan Gupta (1985) serta Govindarajan dan Fisher (1990) yang mendukung proposisi Miles dan Snow (1978) dengan hasil penelitian yang dilakukan Simons (1987). Kontradiksi ini menyebabkan tidak jelasnya pengaruh strategi kompetitif yang diterapkan perusahaan terhadap efektivitas sitem kontrol akuntansi meningkatkan kinerja perusahaan.

Kesesuaian (match) yang lebih baik antara sistem kontrol dengan variabel kontinjensi dihipotesakan pada beberapa penelitian menghasilkan kinerja organisasi yang meningkat (Fisher,1998). Untuk menghasilkan kesimpulan yang bebas multikoliaritas maka logika pengujian menggunakan logika analisis residual dengan memperhatikan korelasi negatif antara kinerja dengan nilai residual variabel kontinjen dan variabel sistem untuk membuktikan pengaruh positif variabel kontinjen terhadap hubungan variabel sistem dengan kinerja.

Penelitian Mak (1989) menghipotesiskan bahwa deviasi (residual) sistem kontrol akuntansi dan ketidakpastian lingkungan yang dipersepsikan berhubungan (korelasi) negatif terhadap kinerja perusahaan. Hal tersebut menunjukkan dugaan bahwa ada pengaruh positif ketidakpastian lingkungan yang dipersepsikan terhadap hubungan sistem kontrol akuntansi dengan kinerja perusahaan sebagaimana yang dihipotesiskan oleh Sim dan Teoh (1999).

Penelitian Govindarajan dan Gupta (1985) dalam Smith (1997) menguji hipotesis yang menyatakan bahwa strategi kompetitif berpengaruh positif terhadap hubungan sistem kontrol akuntansi dengan kinerja perusahaan. Dalam logika analisis residual maka dapat diartikan bahwa adanya hubungan negatif antara kinerja perusahaan dengan residual sistem kontrol akuntansi dan strategi kompetitif.

Hipotesis yang diajukan dalam penelitian ini adalah:

H1 : Ketidak pastian lingkungan yang dipersepsikan berpengaruh terhadap hubungan sistem kontrol akuntansi dengan kinerja perusahaan

H2 : Strategi kompetitif berpengaruh terhadap hubungan sistem kontrol akuntansi dengan kinerja perusahaan 


\section{Gambar 1}

Pengaruh Ketidak pastian Lingkungan yang Dipersepsikan dan Strategi Kompetitif Terhadap Hubungan Sistem Kontrol Akuntansi dengan Kinerja Perusahaan

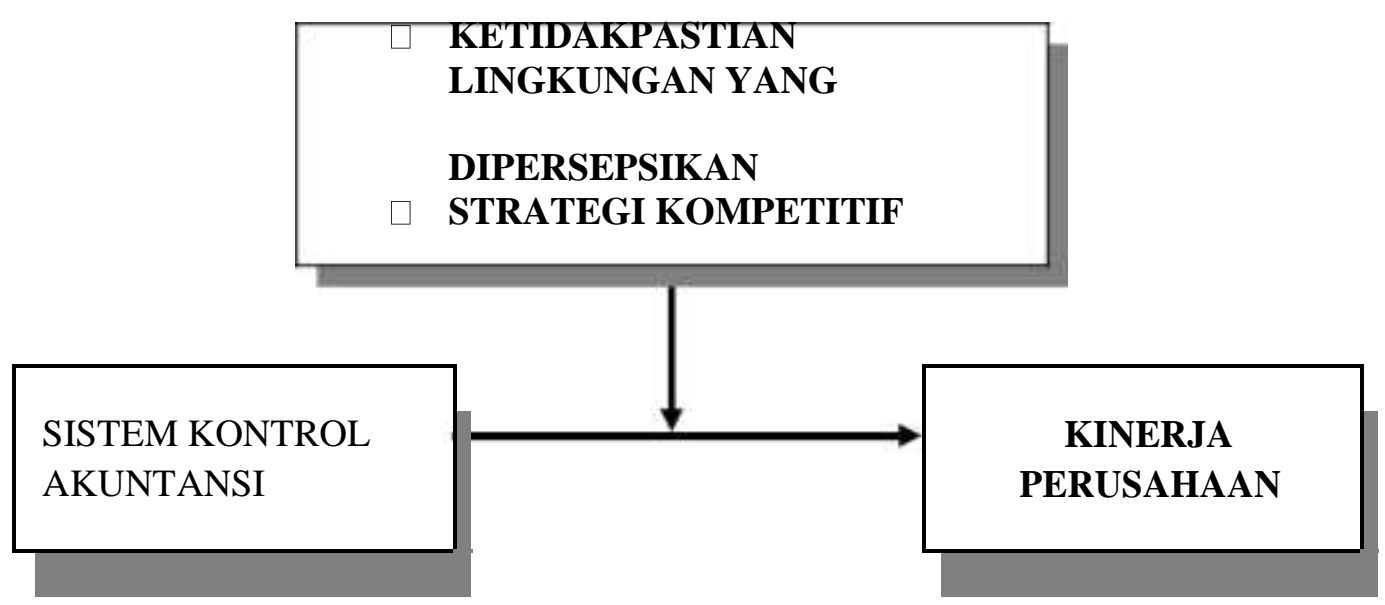

Sumber : Mak (1989);Govindarajan (1988); Govindarajan dan Gupta (1985) 


\section{METODE PENELITIAN}

\section{Populasi dan Sampel}

Populasi penelitian ini adalah seluruh perusahaan perbankan di kota Medan. Untuk memudahkan pengambilan sampel penelitian maka penelitian ini menggunakan rerangka sampel daftar bank yang beroperasi medan disajkan oleh Bank Indonesia medan

Prosedur untuk pengambilan sampel dalam peneliian ini adalah purposive sampling. Purposive Sampling merupakan teknik pemilihan sampel yang berdasarkan pada pertimbanganpertimbangan tertentu yang berdasarkan tujuan penelitian (Sekaran 1992). Sampel pada penelitian ini adalah perusahaan perbankan pemerintah dan swasta yang beroperasi di kota Medan dimana satu perusahaan diwakili oleh satu responden dengan jabatan presiden direktur atau direktur utama karena penelitian ini berhubungan dengan strategi kompetitif yang diterapkan perusahaan. Presiden direktur atau direktur utama diasumsikan sebagai pihak yang kompeten memahami dan ikut terlibat langsung dalam pengambilan keputusan tentang strategi kompetitif tersebut. Adapun jumlah populasi dalam penelitian ini menurut rerangka sampel yaitu 130 bank yang beroperasi di kota Medan bank milk pemerintah maupun.Dalam penelitian ini jumlah sampel data yang digunakan memperhatikan kecukuan sampel minimal yaitu 30 data,dimana perusahaan yang ikut dalam penelitian ini memiliki keseragaman karakteristk yaitu sama-sama perusahaan perbankan dan berada dalam lingkungan bisnis yang sama.

\section{Validitas dan Reliabilitas Instrumen Variabel}

Ada tiga prosedur yang dilakukan dalam penelitian ini untuk mengukur

kualitas data, yaitu :

(1) Uji konsistensi internal (reliabilitas) ditentukan dengan koefisien Cronbach

Alpha. Pengujian ini menentukan konsistensi jawaban responden atas suatu instrumen penelitian. Hair et. al (1996) mensyaratkan suatu instrumen yang reliabel jika memiliki koefisien Cronbach Alpha diatas 0,70.

(2) Uji validitas instrumen terdiri dari :

a. Uji validitas konstruk menggunakan analisis faktor dengan Varimax Rotation

(Imam Ghozali, 2000). Pengujian ini menentukan kualitas instrumen sistem kontrol akuntansi dengan melihat nilai loading factor masing-masing item instrumen. Suatu instrumen penelitian yang valid disyaratkan memiliki loading factor lebih besar dari 0,50 (Hair et al, 1996).

b. Uji Pearson correlation antara skor masing-masing item pertanyaan dengan total skor pertanyaan. Pengujian ini digunakan untuk melihat validitas konstruk data variabel ketidakpastian lingkungan yang dipersepsikan dan kinerja perusahaan.

Uji Pearson correlation digunakan untuk menguji validitas konstruk data variabel strategi kompetitif dengan mengkorelasikan data yang dihasilkan instrumen I (butir no.60) dengan data yang dihasilkan instrumen II (butir no.34 s/d 39). Korelasi posistif dan signifikan berarti data yang dikumpulkan dengan instrumen tersebut valid sebagaimana telah didemonstrasikan oleh Govindarajan dan Fisher (1990). 


\section{Teknik Analisis Data}

Untuk memberikan deskripsi tentang karakter variabel penelitian (sistem kontrol akuntansi, ketidakpastian lingkungan yang dipersepsikan,strategi kompetitif,dan kinerja perusahaan) digunakan tabel distribusi frekuensi yang menunjukkan angka modus, kisaran skor dan standar deviasi. Penggunaan modus ditujukan untuk mengetahui lebih akurat ukuran tendensi pusat masing-masing data variabel penelitian sehingga dapat diketahui kecderungan dominasi jawaban responden.

Untuk menguji hipotesis penelitian ini digunakan analisis residual (residual analisys). Pendekatan ini dikemukakan oleh Dewar dan Werbel (1979), Drazin dan Van de ven (1985), Duncan dan Moores (1989) untuk mengantisipasi masalah asumsi klasik multicollinearity sehingga kesimpulan penelitian dapat dihasilkan dengan tepat (tidak bias).

Secara umum ada dua langkah dalam analisis residual. Pertama, menentukan nilai residual absolut dengan menggunakan model regresi kontinjensi (gambar 2) atau persamaan residual (gambar 3). Nilai residual menunjukkan ketidaksesuaian lack of fit antara variabel sistem dan variabel kontinjensi. Kedua, menguji hipotesis penelitian dengan memperhatikan korelasi signifikan negatif antara nilai absolut residual dengan kinerja. Nilai korelasi negatif dan signifikan menunjukkan dukungan

terhadap hipotesis penelitian (Duncan dan Moores, 1989). Tingkat signifikansi ditentukan dalam penelitian ini $5 \%$.

Untuk memudahkan dan akurat, nilai residual secara absolut dihitung dengan program pengolah statistik SPSS versi 11.0 dan selanjutnya nilai residual dapat dikorelasikan dengan kinerja perusahaan untuk menguji hipotesis penelitian ini.

\section{Gambar 2}

\section{Model Regresi Kontinjensi Residual}

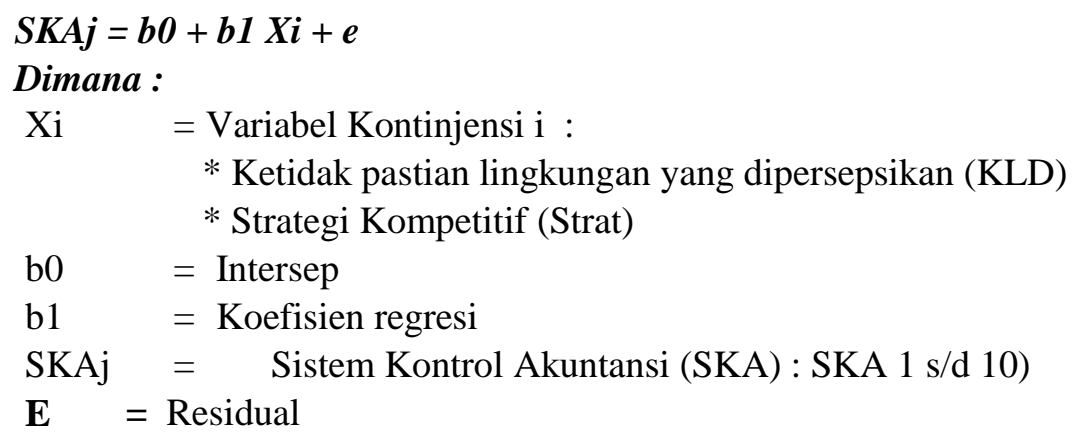

Sumber: Duncan dan Moores (1989)

Gambar 3

Model Persamaan Nilai Residual

$\square$ RES ij $\square=$ SKAj $-b 0-(b 1 *$ Xi) 


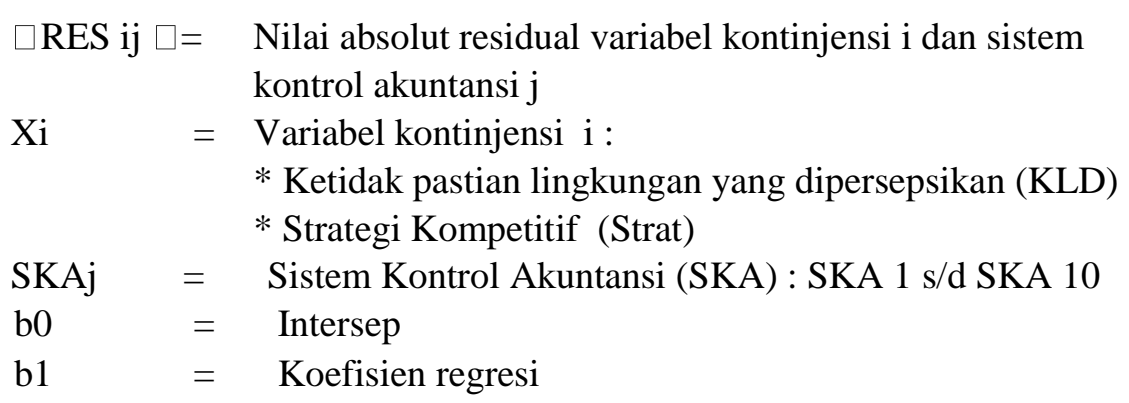

Sumber : Duncan dan Moores (1989) 


\section{HASIL DAN PEMBAHASAN}

Untuk memberikan gambaran mengenai variabel-variabel penelitian digunakan tabel distribusi yang menunjukkan nilai mean dan modus, standar deviasi, dan kisaran aktual sebagaimana dijelaskan pada Tabel 1 . Untuk variabel strategi kompetitif disajikan dengan menggunakan nilai modus dimana skor jawaban responden atas variabel strategi kompetitif dengan standar deviasi 1,011 dan nilai modus -1. Nilai modus 1 menunjukkan bahwa responden lebih banyak menggunakan strategi low cost. Sedangkan kisaran skor jawaban responden untuk variabel sistem kontrol akuntansi antara 69 sampai dengan 74 dengan standar deviasi 1,459 dan nilai mean 70,78. Nilai modus variabel sistem kontrol akuntansi tersebut menunjukkan responden cenderung menganggap perusahaan tempat mereka bekerja menerapkan sistem kontrol akuntansi dengan standar yang rendah.

Untuk variabel ketidakpastian lingkungan yang dipersepsikan skor jawaban responden berkisar antara 39 sampai dengan 54 dengan standar deviasi 3,866 dan nilai mean 50,26. Nilai mean yang mendekati skor maksimum ini menunjukkan bahwa responden merasakan perusahaan tempat ia bekerja cenderung menghadapi ketidak pastian lingkungan yang tinggi. Untuk variabel kinerja perusahaan skor jawaban responden berkisar antara 36 sampai dengan 48 dengan standar deviasi 3,407 dan nilai mean 44,76. Nilai mean yang mendekati skor maksimum tersebut menunjukkan kecenderungan responden menganggap perusahaannya memiliki kinerja yang tinggi.

TABEL 1

STATISTIK DESKRIPTIF

\begin{tabular}{|c|c|c|c|c|c|}
\hline VARIABEL & MEAN & MODUS & S. DEV & SKOR MIN & SKOR MAK \\
\hline $\begin{array}{l}\text { SISTEM KONTROL } \\
\text { AKUNTANSI } \\
\text { (SKA) }\end{array}$ & 70,78 & & 1,459 & 69 & 74 \\
\hline $\begin{array}{l}\text { KETIDAKPASTIAN } \\
\text { LINGKUNGAN } \\
\text { YANG DIPERSEPSIKAN } \\
\text { (KLD) }\end{array}$ & 50,26 & & 3,866 & 39 & 54 \\
\hline STRATEGI KOMPETITIF & - & -1 & 1,011 & -1 & 1 \\
\hline $\begin{array}{l}\text { KINERJA PERUSAHAAN } \\
\text { (KP) }\end{array}$ & 44,76 & & 3,407 & 36 & 48 \\
\hline
\end{tabular}

Sumber : lampiran B, 2002 
Berdasarkan Tabel 2 diketahui bahwa nilai Cronbach Alpha masing - masing instrumen yang digunakan dalam penelitian ini diatas 0,60 yang mengisyaratkan bahwa data yang dikumpulkan menggunakan instrumen-instrumen tersebut reliabel dimana responden telah menjawab semua pertanyaan secara konsisten.

TABEL 2

HASIL UJI RELIABILITAS VARIABEL PENELITIAN

\begin{tabular}{|c|l|c|}
\hline NO. & \multicolumn{1}{|c|}{ VARIABEL } & $\begin{array}{c}\text { CRONBACH } \\
\text { ALPHA }\end{array}$ \\
\hline 1 & SISTEM KONTROL AKUNTANSI & 0,7523 \\
\hline 2 & $\begin{array}{l}\text { KETIDAKPASTIAN LINGKUNGAN YANG } \\
\text { DIPERSEPSIKAN }\end{array}$ & 0,7395 \\
\hline 3 & STRATEGI KOMPETITIF & 0.9041 \\
\hline 4 & KINERJA PERUSAHAAN & 0,6886 \\
\hline
\end{tabular}

Sumber : lampiran C, 2007

Pada Tabel 3 dijelaskan mengenai validitas instrumen sistem kontrol akuntansi. Untuk instrumen sistem kontrol akuntansi dari 33 item pertanyaan maka hanya 12 item pertanyaan yang valid (no. x3, x4, x5, x7, x9, x22, x23, x24, x27, x28, x29, x32) yang mampu menjelaskan dimensi sistem kontrol akuntansi dan item-item pertanyaan tersebut mampu menjelaskan 9 dimensi sistem kontrol akuntansi dari 10 dimensi yang telah diidentifikasi oleh Simon (1987). Sedangkan untuk instrumen ketidakpastian lingkungan yang dipersepsikan dan kinerja perusahaan dijelaskan dalam Tabel 9 dan terbukti bahwa semua item pertanyaan valid. Begitu juga pada Tabel 10 dijelaskan bahwa semua item pertanyaan instrumen strategi kompetitif terbukti valid. 


\section{Jurnal Widya}

Volume 2, Nomor 1, April 2021 halaman 8-28

https://jurnal.amikwidyaloka.ac.id/index.php/awl

jurnal@amikwidyaloka.ac.id / editor.jurnalwidya@gmail.com

TABEL 3

VALIDITAS INSTRUMEN KETIDAKPASTIAN LINGKUNGAN YANG DIPERSEPSIKAN (KLD) DAN KINERJA PERUSAHAAN (KP)

\begin{tabular}{|c|c|c|c|}
\hline & KLD & SIGNIFIKAN & $\overline{\text { STATUS }}$ \\
\hline KLD & 1,000 & & \\
\hline $\mathrm{X} 52$ & 0,380 & 0,009 & VALID \\
\hline $\mathrm{X} 53$ & 0,659 & 0,000 & VALID \\
\hline $\mathrm{X} 54$ & 0,806 & 0,000 & VALID \\
\hline $\mathrm{X} 55$ & 0,760 & 0,000 & VALID \\
\hline $\mathrm{X} 56$ & 0,416 & 0,004 & VALID \\
\hline $\mathrm{X} 57$ & 0,737 & 0,000 & VALID \\
\hline $\mathrm{X} 58$ & 0,716 & 0,000 & VALID \\
\hline $\mathrm{X} 59$ & 0,453 & 0,002 & VALID \\
\hline & $\overline{\mathrm{KP}}$ & SIGNIFIKAN & \\
\hline KP & 1,000 & & \\
\hline $\mathrm{X} 40$ & 0,576 & 0,000 & VALID \\
\hline $\mathrm{X} 41$ & 0,701 & 0,000 & VALID \\
\hline $\mathrm{X} 42$ & 0,755 & 0,000 & VALID \\
\hline $\mathrm{X} 43$ & 0,757 & 0,000 & VALID \\
\hline $\mathrm{X} 44$ & 0,784 & 0,000 & VALID \\
\hline $\mathrm{X} 45$ & 0,334 & 0,023 & VALID \\
\hline $\mathrm{X} 46$ & 0,384 & 0,008 & VALID \\
\hline $\mathrm{X} 48$ & 0,526 & 0,000 & VALID \\
\hline
\end{tabular}

Sumber : lampiran D, 2007

JURNAL WIDYA This work is licensed under a Creative Commons Attribution-NonCommercialShareAlike 4.0 International License. 
TABEL 10

VALIDITAS INSTRUMEN STRATEGI KOMPETITIF

\begin{tabular}{|c|c|c|}
\hline ITEM & $\begin{array}{r}\text { KOEFISIEN } \\
\text { KORELASI }\end{array}$ & STATUS \\
\hline X34 & 0,875 & VALID \\
\hline X35 & 0,964 & VALID \\
\hline X36 & 0,520 & VALID \\
\hline X37 & 0,900 & VALID \\
\hline X38 & 0,950 & VALID \\
\hline X39 & 0,995 & VALID \\
\hline
\end{tabular}

Sumber : lampiran D, 2007

menggunakan analisis residual yang dioprasionalkan melalui program pengolah statistik SPSS versi 11.0 dengan tingkat signifikansi $5 \%$ maka diketahui bahwa hipotesis 1 ditolak terbukti dengan koefisien korelasi antara kinerja perusahaan dengan residual sistem kontrol akuntansi dan ketidakpastian lingkungan yang dipersepsikan (reskld) tidak signifikan ( $\mathrm{p} \geq 5 \%$ ) Berikut ini tabel 11 akan merinci hasil uji hipotesis 1.

TABEL 11

\section{KOEFISIEN KORELASI DAN SIGNIFIKANSI HASIL UJI ～HIPOTESIS 1}

\begin{tabular}{|c|c|c|}
\hline RESIDUAL & $\begin{array}{c}\text { KINERJA } \\
\text { PERUSAHAAN }\end{array}$ & SIGNIFIKANSI \\
\hline RESKLD1 & $-0,125$ & 0,408 \\
\hline RESKLD3 & $-0,45$ & 0,767 \\
\hline RESKLD4 & $-0,45$ & 0,767 \\
\hline RESKLD5 & $-0,124$ & 0,413 \\
\hline RESKLD6 & 0,019 & 0,898 \\
\hline RESKLD7 & 0,173 & 0,250 \\
\hline
\end{tabular}

JURNAL WIDYA This work is licensed under a Creative Commons Attribution-NonCommercialShareAlike 4.0 International License. 


\begin{tabular}{|c|c|c|} 
RESKLD8 & $-0,59$ & 0,697 \\
\hline RESKLD9 & 0,57 & 0,709 \\
\hline RESKLD10 & $-0,97$ & 0,522 \\
\hline
\end{tabular}

Sumber : lampiran E, 2007

Dari hasil pengujian terbukti bahwa hipotesis 1 ditolak karena koefisien korelasi antara kinerja perusahaan dengan nilai residual sistem kontrol akuntansi dan ketidak pastian lingkungan yang dipersepsikan menunjukkan siginifikansi lebih besar dari signifikansi yang disyaratkan ( $\mathrm{p} \square$ $0,05)$ walaupun beberapa nilai residual antara sistem kontrol akuntansi dan ketidakpastian lingkungan yang dipersepsikan

berkorelasi negatif dengan kinerja perusahaan. Temuan penelitian ini bertolak belakang dengan hasilhasil penelitian Mak (1989) yang menyimpulkan bahwa kinerja perusahaan berhubungan negatif dengan nilai residual sistem kontrol akuntansi (operasional) dan ketidakpastian lingkungan yang dipersepsikan. Hasil pengujian tersebut dapat diartikan bahwa ketidakpastian lingkungan

yang dipersepsikan top manajemen tidak berkesesuaian dengan sistem kontrol akuntansi yang diterapkan perusahaan.

Pada statistik deskriptif telah dijelaskan bahwa karakteristik data untuk variabel ketidakpastian lingkungan yang dipersepsikan menunjukkan bahwa responden dalam hal ini top manajer dominan merasa bahwa perusahaan mereka berada dalam ketidakpastian lingkungan yang tinggi. Hal ini sesuai dengan kondisi ketidakpastian lingkungan yang tinggi dihadapi industri perbankan setelah era krisis ekonomi dengan banyaknya pengawasan baik dari pemerintah atau masyarakat secara umum. Fenomena "RUSH" sangat ditakuti di dunia perbankan baik efek informasi riil maupun asimetri informasi yang diterima masyarakat. Secara teoritis temuan ini mendukung pernyataan Koberg dan Ungson (1987); Gordon dan Narayanan (1984) bahwa perusahaan yang berada dalam ketidakpastian lingkungan yang tinggi cenderung lebih menggunakan sistem kontrol organik (non-akuntansi) untuk mencapai kinerja.

Perusahaan yang berada dalam lingkungan yang ketidakpastiannya tinggi cenderung akan mengurangi intensitas penggunaan sistem kontrol akuntansi dan lebih menggunakan sistem kontrol lainnya seperti sistem kontrol IT untuk menjamin pelayanan real time dinikmati customer termasuk juga perusahaan yang memfokuskan kepekaan menyelesaikan komplain konsumen yang diterima melalui layanan komplain konsumen yang banyak digunakan sebut saja phone banking. Sistem kontrol akuntansi (operasional) cenderung hanya dapat mengatasi tugas-tugas yag sudah terprogram atau sudah pasti (low uncertainty) (Mak, 1989).

Dari hasil uji hipotesis diketahui bahwa hipotesis 2 juga ditolak terbukti dengan koefisien korelasi antara kinerja perusahaan dengan residual sistem kontrol akuntansi dan strategi kompetitif (resstra) tidak signifikan ( $\mathrm{p} \geq 0,05)$ walaupun beberpa residual sistem kontrol akuntansi dan strategi kompetitif menunjukkan tanda negatif sebagaimana terlihat dalam tabel 12.

Hasil pengujian hipotesis menunjukkan bahwa strategi kompetitif tidak berkesesuaian dengan sistem kontrol akuntansi yang diterapkan perusahaan. Pada statistik deskriptif telah dijelaskan bahwa 
karakteristik data variabel strategi kompetitif menunjukkan bahwa perusahaan sampel penelitian dominan menggunakan strategi cost leadership (low cost).

Temuan penelitian ini bertolak belakang dengan hasil-hasil penelitian Govindarajan dan Gupta (1985), Govindarajan (1988), Govindarajan dan Fisher (1990) yang menemukan bahwa sistem kontrol akuntansi dapat meningkatkan kinerja perusahaan yang menerapkan strategi harvest (cost leadership).

Perusahaan yang menerapkan strategi low cost memberikan perhatian terhadap penyediaan produk dengan biaya produksi yang paling efisien (Porter, 1980; 1985) dalam Smith (1997); Sim dan Teoh (1999).Dari jawaban responden yang cenderung mempersepsikan perusahaan mereka berada dalam ketidakpastian yang tinggi dan dominan menerapkan strategi cost leadership.

TABEL 12

KOEFISIEN KORELASI DAN SIGNIFIKANSI HASIL UJI HIPOTESIS 2

\begin{tabular}{|c|c|c|}
\hline RESIDUAL & $\begin{array}{c}\text { KINERJA } \\
\text { PERUSAHAAN }\end{array}$ & \begin{tabular}{l} 
I \\
\hline RESTRA1
\end{tabular} \\
\hline RESTRA3 & $-0,115$ & 0,48 \\
\hline RESTRA4 & $-0,59$ & 0,697 \\
\hline RESTRA5 & $-0,89$ & 0,697 \\
\hline RESTRA6 & 0,13 & 0,588 \\
\hline RESTRA7 & 0,145 & 0,993 \\
\hline RESTRA8 & $-0,54$ & 0,377 \\
\hline RESTRA9 & 0,28 & 0,759 \\
\hline RESTRA10 & $-0,56$ & 0,855 \\
\hline & & 0,711 \\
\hline
\end{tabular}

\section{KESIMPULAN DAN SARAN}

\section{Kesimpulan}

Temuan penelitian ini walaupun belum konkrit menunjukkan bukti pengaruh efektivitas ketidakpastian lingkungan yang diukur melalui persepsi top manajer terhadap hubungan sistem kontrol akuntansi dan kinerja perusahaan namun dapat memberikan isyarat bahwa ketidakpastian lingkungan yang dipersepsikan top manajer sesuai dengangan kondisi aktual.

Saran

Implikasi teoritis sebagai agenda penelitian akan datang dari temuan penelitian ini yaitu bahwa penelitian-penelitian di masa akan datang dapat menguji secara bersama ketidakpastian lingkungan yang dipersepsikan dengan ukuran kondisi aktual dan ukuran persepsi manajer agar dapat 
benar-benar dibandingkan keandalan pengaruhnya terhadap hubungan sistem kontrol akuntansi dengan kinerja perusahaan. Selain itu dapat pula menguji variabel-variabel kontinjensi lainnya yang belum diuji dalam penelitian ini seperti teknologi, budaya organisasi, dan variabel-variabel individual.

\section{DAFTAR PUSTAKA}

[1] Anthony, R.N. dan Govindarajan, Vijay.1998. Mangement Control System. $9^{\text {th }}$ ed. Irwin McGrawhill.

[2] Anthony, D. Dearden, J dan Bedford, N.M.(1991). Sistem Pengendalian Manajemen. Edisi ke-5. Penerbit Erlangga.

[3] Bambang Riyanto L.S. 1999. “ The Effect of Attitude, Strategy, and Decentralization on the Effectiveness of Budget Participation”. Jurnal Riset Akuntansi Indonesia, Vol.2 No.2 Juli.

[4] Belkoui,Ahmed.1986. Handbook of Management Control System, New York. Quorum Books.

[5] Birnberg, Jacob. G. 1998."Some Reflections on the Evolution of Organizational Control". Behavioral Research in Accounting.Vol.10.pp. 27-46.

[6] Brownell, P .1981. "Participation in Budgetting, Locus of Control and Organizational Effectiveness". The Accounting Review. No.4.pp. 845-859.

[7] dan Merchant, K.1990.” The Budgetary And Performance Influences Of Product Standardization And Manufacturing Process Automation". Journal of Accounting Research 28. pp. 29-44.

[8] , dan Mercant, K.A.1990. "The Budgetary and Performance Influence of Product Standardization and Manufacturing Process Automation”. Journal of Accounting Research. No. 28. pp. 388-396.

[9] Caillouet,A dan Lapeyre,B. 1992.“ The Importance of An AccountingInformation Syatem in the Strategic Management Process".SAM Advanced Management Journal. pp.22-24.

[10] Chenhall, R.H dan Morris, D. 1986. "The Impact of Structure, Environment, and Interdependence on The Perceived Usefulness of Management Accounting Systems". The Accounting Review.Vol. 1. XI, No.1 pp. 16 - 35.

[11] Cunningham,G.M. 1992. " Management Control and Accounting Systemunder a Competitive Strategy”. Accounting ,Auditing, \& Accountability Journal.Vol.5 pp. 85-102.

[12] Dewar, R. dan Werbel, J. 1979. " Universalitic and Contingency Predictions of Employee Satisfaction and Conflict”. Administrative Science Quaterly 
September Vol.24. pp. 426-444

[13] Dearden, J. 1987. "Measuring Profit Centre Managers".Harvard Bussiness Review September-Oktober pp.81-88.

[14] Dent,J,F.1990."Strategy, Organization and and Control : Some Possibilities for Accounting Research", Accounting, Organizatins and Society.pp. 3-24.

[15] Downey, H.K, Hellriegel,J.L, dan Slocum, J.W. 1975. "Environmental Uncertainty : The Construct and Applications". Administrative Science Quarterly. 20 : 161-173.

[16] Drazin, R. dan Van de Ven, A.H. 1985."Alternative Forms of Fit in Contingency Theory". Administrative Science Quarterly Vol. 30. pp. 514-539.

[17] Duncan, K, Moores,K. 1989." Residual Analysis : A Better Methodology for Contingency Studies in Management Accounting". Journal Management Accounting Research Vol.1. pp. 89-103.

[18] Fisher, J.G. 1998. "Contingency Theory, Management Control Systems and Firm Outcomes : Past Result and Future Directions”. Behavioral Research in Accounting Vol.10.pp.48-63.

[19] Gerloff, E.A, Muir, N.K, dan Bodensteiner, W.D. 1991. "Three Components of Perceived Environmental Uncertainty : An Exploratory Analisys of The Effects of Aggregation". Journal of Management 17 : 749-768.

[20] Govindarajan, V.1984. "Appropriate ness of Accounting Data In Performance Evaluation". Accounting, Organization, and Society. Vol.9 pp.125-135.

[21] ___ dan Gupta, A.K. 1985. "Linking Control System to Business Unit Strategy : Impact on Performance. Accounting, Organization, and Society. Pp. 51-66.

[22] _ 1988. "A Contingency Approach to Strategy Implementation at the business - Unit Level : Integrating Administrative Mechanisms with

Strategy”. Academy of Management Journal. Pp. 828- 853.

[23]___ dan Fisher,J. 1990. "Strategy, Control Systems Dan Resource Sharing:

Effects On Bussines - Unit Performance “. Academy of Management Journal. 33. pp. 259285.

[24] Gordon, L dan Narayanan, V.K. 1984). "Management Accounting Systems, Perceived Environment Uncertainty and Organizations Structure : An Empirical Investigation". Accounting, Organizations, and Society 9: 33-47.

\section{JURNAL WIDYA This work is licensed under a Creative Commons Attribution-NonCommercial- ShareAlike 4.0 International License.}


[25] Gupta, A.K and Govindarajan, V. 1984. "Business Unit Strategy, Managerial Characteristic, and Business Unit Effectiveness at Strategy Implementation",

Academy of Management Journal. pp.25-41.

[26] Gujarati, D.1995. Basic Econometrics. 3rd ed.International Edition. McGraw-Hill.

[27] Gul,F.A dan Chia, Y.M.1994."The Effects of management accounting systems, perceived environmentaluncertainty and decentralization on managerial performance: Atest of a ThreeWay Interactions".Accounting, Organizations and Society Vol.19 pp. 413-426.

[28] Harahap,Sofyan Syafri. 2001. Sistem Pengawasan Manajemen. Cetakan pertama. Pustaka Quantum.

[29] Jaeger,A . 1983. "The Transfer of Organizational Culture Overseas An Approachto Control in the Multinational Corporation". Journal of Business Studies.pp. 91-114.

[30] Kalagnanam, S.S dan Lindsay, R.M. 1998. “ The Use of Organic Models of Control in JIT Firms : Generalising Woodward's Findings to Modern Manufacturing Practices". Accounting, Organizations, and Society 24 pp. 1-30.

[31] Kaplan, R.S. 1984. "The Evolution of Management Accounting “.The Accounting Review. pp. 390-418.

[32] Khandwalla, P.N. 1972. "The Effect of Different Types of Competition on The Use of Management Controls". Journal of Accounting Research. Pp.275-285.

[33] Kren, Leslie.1997. The Role of Accounting Information in Organization Control : State of The Art. Behavioral accounting Research: Foundations and Frontiers. American Accounting Association.

[34] Koberg, C.S dan Ungson,G.R. 1987. "The Effects of Environmental Uncertainty and Dependence on Organizational Structure and Performance : Acomparative Study". Journal of Management Vol.13 N0.4. pp. 725-737

[35] ___ dan Kerr, J.L. 1993. "The Effect of Behaviour Monitoring and Uncertainty on The Use of Performance - Contingent Compensation“. Accounting and Bussiness Research 23 : 159168.

[36] Mak. Yuen Teen. 1989. Contingency Fit, Internal Consistency and Financial Performance. Journal of Business Finance \& Accounting 16.2.Spring. pp.273-300.

[37] Merchant, Kenneth A. 1984. "Influence on Departemental Budgetting An Empirical Examination of A Contingency Model “. Accounting, Organization, and Society. Vol.9. pp. 291-377. 
[38] 1981. "The Design of The Corporate Budgetting System : Influence on Managerial Behavior and Performance". The Accounting Review. 56. pp. 813-827.

[39] Miles, R.W. dan Snow ,C.C .1978. Organizational Strategy, Structure, and Process . New York : McGraw-Hill.

[41] Miller, D and Friesen,P.H. 1982.” Innovation in Concervative and Enterpreneurial Firms : Two Models of Strategic Momentum. Strategic” Management Journal. pp. 1-25.

[42] Milliken,F.J. 1987. "Three Types of Perceived Uncertainty about The Environment :

State, Effect, and Response Uncertainty”. Academy of Management Review. 12 : 133-143.

[43] Palmer,R.J.1992. "Strategic Goals And Objectives And The Design Of Strategic Management Accounting Systems". Advances in Management Accounting

Vol.1 pp. 179-204.

[44] Simons, R 1987. "Accounting Control System and Business Strategy : An Empirical Analysis". Accounting, Organizations, and Society. Pp.357-374.

[45] __ 2000. Performance Measurement \& Control Systems For Implementing. 7th ed. Prentice Hall.

[46] Sisaye, Saleshi.1998. "An Overview of the Social and Behavioral Science Approaches in Mangement Control Research". Behavioral Research in Accounting. Vol. 10. pp.12-25.

[47] Smith, K.L. 1997.

Strategy : Review”. Accounting Organizations and Society. Vol.22. No.2 pp. 207-232.

[48] Tymon, Jr, W.G. Stout, D.E. dan Shaw K.N.1998. "Critical Analysis and Recommendations Regarding the Role of Perceived Environmental Uncertainty in Behavioral Accounting Research". Behavioral Research in Accounting. Vol. 10 pp. $24-45$.

[49] Waterhouse,J.H dan Tiessen,P.1978.'The Contingency Framework for Management Accounting System Research". Accounting, Organization, and Society.Vol.3. No.1.pp. 65-76. 